\title{
Radial variation in modulus of elasticity, microfibril angle and wood density of veneer logs from plantation-grown Eucalyptus nitens
}

\author{
Mario Vega $^{1,2}$ (D) Matthew Hamilton ${ }^{1,3} \cdot$ Geoff Downes $^{4} \cdot$ Peter A. Harrison ${ }^{1,2}$ • Brad Potts ${ }^{1,2}$ \\ Received: 18 August 2019 / Accepted: 11 May 2020 / Published online: 25 June 2020 \\ (C) INRAE and Springer-Verlag France SAS, part of Springer Nature 2020
}

\begin{abstract}
- Key message Radial variation of wood properties affects product recovery from veneer logs. In Eucalyptus nitens, the radial variation in wood density, microfibril angle and modulus of elasticity was described using non-linear models. The timing of radial change was trait-dependent, and the age at which thresholds for structural products were reached differed between sites.

- Context Eucalyptus nitens is widely planted in cool temperate regions of the world. While mainly grown for pulpwood, rotarypeeled veneer is becoming important. Threshold levels of wood stiffness are required for using this veneer for structural purposes. Stiffness is determined by wood density and microfibril angle, which improve with tree age. The nature of this radial variation affects the recovery of suitable veneer and profitability of the plantation resource.

- Aims We model the radial variation of these veneer-critical wood properties and determine whether it varies with growing conditions.

- Methods We used logs from three 20-22-year-old Tasmanian plantations. Radial variations in wood density, microfibril angle and modulus of elasticity (measuring stiffness) were assessed using SilviScan. Eight linear and non-linear models were examined using cambial age as the independent variable.

- Results The increases in wood density and modulus of elasticity with age were modelled by sigmoidal functions and the decrease in microfibril angle modelled by an asymptotic function. The timing of radial change was trait-dependent, and the mean ages at which thresholds for structural products were reached between sites.

- Conclusion Radial variation varied among sites and will likely impact the recovery of structural grade veneer from plantations.
\end{abstract}

Keywords SilviScan $\cdot$ MOE $\cdot$ MFA $\cdot$ Juvenile wood $\cdot$ Corewood $\cdot$ Structural plywood

Responsible editor: Jean-Michel Leban

Contributions of the co-authors Conceptualisation: $\mathrm{MV}, \mathrm{MH}$, and BMP; methodology and data analysis: MV, MH, GD, PAH and BMP; data collection: $\mathrm{MV}$ and GD; writing, reviewing, and editing: $\mathrm{MV}, \mathrm{MH}$, GD, PAH and BMP.

Mario Vega

Mario.Vegarivero@utas.edu.au

Matthew Hamilton

M.Hamilton@cgiar.org

Geoff Downes

geoff.downes@forestquality.com

Peter A. Harrison

P.A.Harrison@utas.edu.au
Brad Potts

b.m.potts@utas.edu.au

1 School of Natural Sciences, University of Tasmania, Private Bag 55, Hobart, Tasmania 7001, Australia

2 ARC Centre for Forest Value, University of Tasmania, Private Bag 55, Hobart, Tasmania 7001, Australia

3 The WorldFish Center, PO Box 500 GPO, 10670 Penang, Malaysia

4 Forest Quality Pty Ltd, PO Box 293, Huonville, Tasmania 7109, Australia 


\section{Introduction}

In forest trees, wood properties usually vary systematically in the stem from pith to cambium. In general, in the first years, there is a rapid annual progression in a suite of wood properties such as wood density, microfibril angle in the S2 layer of the cell wall and the modulus of elasticity (Burdon et al. 2004; Moore and Cown 2017). For modulus of elasticity and microfibril angle, this progression is typically monotonic, but changes in wood density are dependent on the particular species. Eventually, a cambial age (number of rings from the pith) is reached at which these radial changes are extremely gradual and tend to stabilize (i.e. approach asymptotes) (Kojima et al. 2009; Lachenbruch et al. 2011; Moore and Cown 2017). Such radial changes in wood properties mean it is possible to identify in mature trees a corewood (so-called 'juvenile wood') that is adjacent to the pith and the outerwood (so-called 'mature wood') that is near to the cambium (Burdon et al. 2004; Moore and Cown 2017). Nevertheless, there is no definitive or universally accepted boundary between corewood and outerwood as the radial progression is often gradual depending on the wood property evaluated and can be specific to an individual tree. This zone between the corewood and outerwood is often referred to as the 'transition wood' (Burdon et al. 2004; Lachenbruch et al. 2011). Within a single species, the radial variation, including the amount and proportion of corewood, and outerwood, as well as the rate of transition within the stem, will be influenced by environmental, silvicultural and genetic factors (Burdon et al. 2004; Lachenbruch et al. 2011; Lenz et al. 2010; Maeglin 1987; Zobel and van Buijtenen 1989).

The radial variation in wood properties has direct implications for the processing and utilisation of wood, for example in the production of rotary-peeled veneer, which is the basis for plywood and laminated veneer lumber (LVL). Predictions of average wood properties for a tree or log give general information about potential veneer recovery of a given quality (Blackburn et al. 2018a, b; McGavin et al. 2015). However, radial profile models permit more accurate estimation of potential veneer recovery by, for example, estimating the volume of veneer with a specific mechanical grade (Leban and Haines 1999; Maeglin 1987; Moore et al. 2014). Such grading is important because the mechanical properties define product value (Blackburn et al. 2018a, b; Lachenbruch et al. 2011; Maeglin 1987; McGavin et al. 2014a). In economic terms, global market trends have shown that plywood, particularly non-structural plywood, is nearing saturation, meaning that the industry is facing very high competition (Buehlmann and Schuler 2013). Conversely, demand for structural products such as LVL is in an expansion phase (Buehlmann and Schuler 2013; Blackburn et al. 2018a). As such, the structural grading of wood products has direct implications for industry profitability.

Among the wood properties, wood stiffness as quantified by the modulus of elasticity is a key factor determining the value of structural timber and veneer (Blackburn et al. 2018a, b). Modulus of elasticity is affected by both wood density and the microfibril angle (Barnett and Bonham 2004; Evans and Ilic 2001). In addition to their effect on modulus of elasticity, wood density and microfibril angle have independent roles in the performance of solid-wood products. Wood density affects hardness and machinability, whereas microfibril angle affects stability during drying and in service (Burdon et al. 2004).

A number of different linear and non-linear models have been used to predict radial trends in wood density, microfibril angle and modulus of elasticity, with the aim of improving forest resource characterisation (Burkhart and Tomé 2012; Maeglin 1987). Radial trends have been modelled for a range of species, but the majority of research has focused on conifers (Burdon et al. 2004; Maeglin 1987; Moore et al. 2014; Sattler et al. 2014; Zobel and van Buijtenen 1989). Cambial age (ring number from pith) is the most common independent variable used in modelling radial variability (Auty and Achim 2008; Auty et al. 2013, 2018; Leban and Haines 1999; Lenz et al. 2010; Moore et al. 2014; Xiang et al. 2014). The advantage of using the cambial age is the capacity to cross-reference data at ring level, as well as the possibility of linking with growth and yield models (Mendoza and Vanclay 2008). In a veneer study with eucalypts, McGavin et al. (2015) recommended using cambial age for increased accuracy, but practical constraints required them to use distance from pith, as measured from the veneer ribbon.

The present study aimed to model radial variation in wood density, microfibril angle and modulus of elasticity of plantation-grown Eucalyptus nitens (Deane \& Maiden) Maiden in Tasmania. Eucalyptus nitens is planted in cool temperate regions of the world (Hamilton et al. 2011). Australia is a major grower (233,600 ha), with most plantations on the southern island state of Tasmania (208,200 ha) (Downham and Gavran 2019). While most of the Tasmanian E. nitens estate is managed for pulpwood, $30 \%$ has been pruned and thinned and is being managed for solid-wood products, and components of the estate managed under pulpwood silvicultural regimes are now being harvested for veneer logs (Blackburn et al. 2018a). Wood density, microfibril angle and modulus of elasticity are the three veneer-critical wood properties that affect mechanical grading of veneer (Evans and Ilic 2001). Understanding radial variation of these key wood properties is important to determine the technical and economic feasibility of extending beyond the traditional use of this resource (i.e. pulp chips) to higher-value products such as LVL or plywood.

With the broader objective of better characterising the E. nitens plantation resource for veneer production, we studied three Tasmanian $E$. nitens plantations representing a range of environmental and silvicultural characteristics and aimed to

- Identify models that best explain the profile of radial variation in wood density, microfibril angle and modulus of elasticity with respect to cambial age;

\section{Q9 Springer INRAC}


- Apply these models of radial variation to quantify the extent to which the patterns of radial variation in wood properties differ among plantation sites; and

- Predict the age at which wood is produced with a modulus of elasticity suitable for producing veneer that is suitable for use in structural products.

\section{Materials and methods}

\subsection{Field sites and tree selection}

Three contrasting E. nitens plantations at Strathblane, Geeveston and Florentine in the south of Tasmania (Australia) were selected for study (Table 1). These sites are managed by Sustainable Timber Tasmania (formerly Forestry Tasmania) for solid-wood and pulpwood (Table 2) and were previously included in multispecies studies of veneer recovery, quality and log-end splitting (Hamilton et al. 2014; McGavin et al. 2014b, 2015; Vega et al. 2016). While genetic stock involved was unknown, the most Tasmanian E. nitens plantations established approximately 20 years ago were from open-pollinated seed from Central Victoria (Hamilton and Potts 2008). The plantations encompassed different silvicultural treatments and/or site productivities. Strathblane (20 years old) and Geeveston (22 years old) were thinned and pruned for solid-wood production but differed markedly in productivity. The Florentine plantation was 20 years old, unthinned and unpruned, grown for pulpwood. Within each site, a measurement plot ( 972 to $2156 \mathrm{~m}^{2}$ ) was established and average basal area determined.

\subsection{Sample preparation and measurements}

Thirty-eight trees were selected in total, with nineteen from Strathblane, ten from Geeveston and nine from Florentine. Trees were randomly selected at each site, except that trees with any evident visual defects such as double leaders were excluded and, for downstream processing, trees needed to be at least $220 \mathrm{~mm}$ in diameter at breast height over bark $(\mathrm{DBH})_{1.3 \mathrm{~m}}$ (see Vega et al. 2016 for further details). Australian peeling veneer industry uses predominantly butt logs of approximately $5.5 \mathrm{~m}$ (Blackburn et al. 2018a, b). Hence, to estimate the general radial variation trends of wood properties in the butt logs and trees, one disk (50 mm thick) per tree was obtained from $2.5 \mathrm{~m}$ aboveground level immediately after the felling. The disks were stored at $-15^{\circ} \mathrm{C}$ until obtaining the samples to SilviScan.

A pith-to-bark block sample of $20 \mathrm{~mm} \times 15-20 \mathrm{~mm}$ was cut from each of the disks. The block sample was chosen from the longest radial axis of the disk that did not have any defects, such as rot, knots and branches (Fig. 1).

These samples were dehydrated by successive ethanol baths (70\%, 90\% and 100\%), as described by Evans et al. (2000), to prevent collapse, cracking and distortion during air-dry drying (8\% moisture content) and storage. From each dried block sample, one strip sample ( $2 \mathrm{~mm}$ tangentially $\times 8 \mathrm{~mm}$ longitudinally) was obtained using a twin-bladed saw for SilviScan-3 ${ }^{\text {TM }}$ analysis (Downes et al. 2014; Evans et al. 2000).

SilviScan- $3^{\mathrm{TM}}$ was used to simultaneously assess air-dry density at $8 \%$ moisture content (wood density), microfibril angle (MFA) in the S2 layer of the cell wall and dynamic modulus of elasticity (MOE) from pith to cambium on the radial face of the strip samples. Wood density was obtained using an X-ray densitometer with $0.025 \mathrm{~mm}$ resolution and MFA with an X-ray diffractometer with $1 \mathrm{~mm}$ resolution. MOE was predicted based on robust model using wood density and a diffractometric parameter, both related to the orientation and proportion of S2 microfibrils (MFA) (Evans and Ilic 2001; Evans et al. 2000; Evans 2006). MOE was modelled independent of MFA but at the same resolution.

Custom written software using the Interactive Data Language (IDL) was used to define annual ring boundaries in each strip sample based on visual features. These boundaries were then used to determine average wood properties on a ring-by-ring basis.
Table 1 Main site characteristics of the three plantations

\begin{tabular}{|c|c|c|c|}
\hline \multirow[t]{2}{*}{ Location and environment } & \multicolumn{3}{|l|}{ Site } \\
\hline & Strathblane & Geeveston & Florentine \\
\hline Latitude and longitude $\left(^{\circ}\right)$ & $-43.38 ; 146.94$ & $-43.15 ; 146.84$ & $-42.66 ; 146.47$ \\
\hline Altitude (m above sea level) & 153 & 296 & 438 \\
\hline Annual mean temperature $\left({ }^{\circ} \mathrm{C}\right)$ & 10.9 & 10.3 & 9.5 \\
\hline Annual rainfall $(\mathrm{mm})$ & 1161 & 1212 & 1436 \\
\hline Soil description & Sandy over clayey & Loamy over clayey & Yellow podzolic \\
\hline Prevailing winds & Northwest & Northwest & Southwest \\
\hline Site exposure status & Intermediate & Exposed & Intermediate \\
\hline Site index ${ }^{1}(\mathrm{~m})$ & 22.7 & 30.3 & 30.5 \\
\hline
\end{tabular}

${ }^{1}$ Defined as height in meters of dominant and co-dominant trees in a stand at a base of 15 years 
Table 2 Summary statistics for plantations and sample trees

\begin{tabular}{|c|c|c|c|}
\hline \multirow[t]{2}{*}{ Silviculture } & \multicolumn{3}{|l|}{ Site } \\
\hline & Strathblane & Geeveston & Florentine \\
\hline Establishment (year) & 1993 & 1991 & 1993 \\
\hline Management & Thinned and pruned & Thinned and pruned & Pulp \\
\hline Establishment spacing $(\mathrm{m})$ & 2 by 4 & 2.5 by 3 & 2 by 4 \\
\hline Initial stocking (stems ha ${ }^{-1}$ ) & 1250 & 1334 & 1250 \\
\hline Age (year) at thinning [retained stems, ha $^{-1}$ ] & $11[300]$ & 10 [192] & Unthinned \\
\hline Age (year) at pruning [pruning height, $\mathrm{m}$ ] & $3[-]^{1}$ and $5[6]$ & $4[-]^{1}$ and $6[6]$ & Unpruned \\
\hline \multicolumn{4}{|l|}{ Harvest characteristics } \\
\hline Felling age (years) & 20 & 22 & 20 \\
\hline Harvest stocking $\left(\right.$ stems $\mathrm{ha}^{-1}$ ) & 292 & 196 & 669 \\
\hline $\mathrm{DBH}^{2}(\mathrm{~cm})$ & 31.2 & 43.1 & 26.9 \\
\hline Basal area $\left(\mathrm{m}^{2} \mathrm{ha}^{-1}\right)$ & 23.2 & 30.3 & 41.3 \\
\hline $\mathrm{DBH}^{2}$ of sampled trees $(\mathrm{cm})$ & 30.0 & 42.7 & 33.9 \\
\hline Height of sampled trees (m) & 26.9 & 37.5 & 36.4 \\
\hline Slenderness of sampled trees ${ }^{3}$ & 90.5 & 92.0 & 107.8 \\
\hline
\end{tabular}

\subsection{Data analysis}

\subsubsection{Modelling radial trends in wood properties}

The modelling of the radial variation of the wood properties was based on the individual-ring averages and undertaken using non-linear mixed-effects models following the hierarchical approach described by Robinson and Hamann (2011). Eight linear and non-linear mixed-effects models were examined (Table 3). The non-linear models used were either asymptotic or sigmoidal functions. The asymptotic functions included the asymptotic exponential, asymptotic exponential with offset and Michaelis-Menten models, and the sigmoidal functions were logistic with three and four parameters, as well as Weibull and Gompertz models (Logan 2010). The most appropriate model function for each trait was selected, firstly, based on its ability to fit the data for each of the three sites separately (Figs. 3, 4 and 5 in Appendix 5) for cambial age as the independent variable (Sattler et al. 2014), and secondly, following previous studies (Gardiner et al. 2011; Moore et al. 2014), by selecting the model with the lowest Akaike information criterion (AIC) values (Akaike 1974). AIC is a measure of model fit (likelihood function) penalised by the number of parameters and provides a way to evaluate whether more (or less) information pertains to one model over the other (Crawley 2012). These models were initially fitted to the site-level data ignoring tree identity (point-level data) using the $n l s$ function of the R Stats package of R (R Development Core Team 2018).

Wood density was modelled with a four-parameter logistic (sigmoidal) function (Eq. (1))

Wood density $=$ Asym $_{\text {core }}+\frac{\left(\text { Asym }_{\text {outer }}-\text { Asym }_{\text {core }}\right)}{1+e^{\frac{\left(\text { Xmid-Ring }_{\text {scal }}\right.}{\text { sal }}}}$

where Asym $_{\text {core }}$ is the left-hand-side horizontal asymptote corresponding to the wood density of the corewood (at cambial

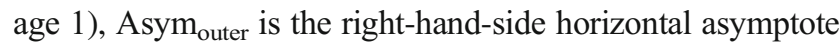
corresponding to the wood density of the outerwood, Xmid is the age in years at which the inflection point of the curve occurs, scal indicates the slope at the inflection point of the curve and Ring is the ring number from pith (analogous to cambial age in years).
Fig. 1 Dimensions and characteristics of the SilviScan strip sample taken from Eucalyptus nitens disks $2.5 \mathrm{~m}$ aboveground level

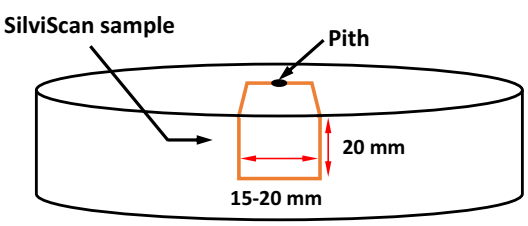


Table 3 Akaike information criterion (AIC) values for eight models tested for the modelling radial variation in the three wood properties against cambial age using pooled point-level data by site

\begin{tabular}{|c|c|c|c|c|c|c|c|c|c|}
\hline \multirow[t]{2}{*}{ Models } & \multicolumn{3}{|c|}{ Wood density $\left(\mathrm{kg} \mathrm{m}^{-3}\right)$} & \multicolumn{3}{|c|}{ MFA (degrees) } & \multicolumn{3}{|l|}{$\operatorname{MOE}(\mathrm{GPa})$} \\
\hline & Strathblane & Geeveston & Florentine & Strathblane & Geeveston & Florentine & Strathblane & Geeveston & Florentine \\
\hline \multicolumn{10}{|l|}{ Cambial age } \\
\hline Linear & 4282 & 2274 & 1915 & 2037 & 1038 & 833 & 1861 & 985 & 817 \\
\hline Asymptotic exponential (Eq. (2)) & - & - & - & 1701 & 961 & 736 & 1775 & 972 & 819 \\
\hline Asymptotic exponential with offset & - & - & - & - & - & - & 1776 & 972 & 819 \\
\hline 3-parameter logistic (Eq. (3)) & - & - & - & - & - & - & 1774 & 968 & 817 \\
\hline 4-parameter logistic (Eq. (1)) & 4257 & 2263 & 1905 & - & 945 & 736 & 1776 & 969 & 917 \\
\hline Weibull & - & - & - & - & - & - & - & - & - \\
\hline Gompertz & - & - & - & 1720 & 739 & 739 & 1774 & 970 & 818 \\
\hline Michaelis-Menten & - & - & - & - & - & - & - & - & - \\
\hline
\end{tabular}

Eqs. (1)-(3) are the equations of the selected models described in the methodology and values in italics show their AIC values, (-) indicates that models did not converge

MFA was modelled with an asymptotic exponential model (Eq. (2))

$\mathrm{MFA}=\mathrm{Asym}_{\text {outer }}+\left(R 0-\mathrm{Asym}_{\text {outer }}\right) \times e^{-e^{\mathrm{ln}} \times \mathrm{Ring}}$

where Asym $_{\text {outer }}$ is the right-hand-side horizontal asymptote corresponding to MFA of outerwood, $R 0$ is the $Y$ intercept, lrc is the natural logarithm of the rate of curvature and Ring is as defined above.

MOE was modelled with a three-parameter logistic (sigmoidal) function (Eq. (3))

$\mathrm{MOE}=\frac{\text { Asym }_{\text {outer }}}{1+e^{\left(\frac{\mathrm{Xnid}_{\text {ming }}}{\text { scal }}\right)}}$

where Asym $_{\text {outer }}$ is the right-hand-side horizontal asymptote corresponding to MOE of outerwood, Xmid is the age in years at which the inflection point of the curve occurs, scal indicates the slope at the inflection point of the curve and Ring is as defined above.

After the selection of the appropriate models for each wood property (Table 3), using the same function, the selected models were fitted to individual tree data and the trees for which model convergence was achieved for all wood properties were identified and this subset of trees used to test the difference in the patterns of radial variation among trees within sites. This testing followed the methodology of Ritz and Streibig (2008), whereby a full model was fitted for each site which included separate parameter estimates for each tree. This model was compared to a constrained model where a single parameter was fitted for the site using ANOVA. In all cases, significant differences were found among trees within sites (Table 5 in Appendix 1) which warranted the fitting of models for individual trees to compare sites.

Final parameter estimates for each tree were obtained using the nlme function of the nlme package of $\mathrm{R}$ (Pinheiro et al. 2018). In the selected model, trees were considered random and a first-order autoregressive correlation structure (AR(1)) was applied among successive cambial ages (Auty et al. 2013; Jordan et al. 2005; Moore et al. 2014). Data from eight trees each from Strathblane and Geeveston and those from nine trees from Florentine were used in the radial modelling. The remaining trees from each site did not converge with the nls or nlme modelling. It is possible that the failure of a larger proportion of trees from the Strathblane site to converge could be due to the responses to thinning and pruning disturbing the normal pattern of radial change at this low-productivity site.

\subsubsection{Comparison among sites}

Inter-site (among-site) variation in model parameters was determined by a one-way ANOVA test using the final individual-tree parameter estimates pooled within sites as replication, weighted by the inverses of their standard errors. This one-way ANOVA was undertaken for each combination of model parameter and wood property estimates using the PROC GLM procedure of SAS $^{\text {TM }}$ (version 9.4; SAS Institute, Cary, NC, USA). For each wood property, the average of the parameters for each site was used to model the radial variation of wood properties at the site level as a function of cambial age. Root mean square error (RMSE) is reported as a measure of the goodness-of-fit of each model at each site and was calculated using the average ring value of the modelled wood property. The average radial trends for each site modelled using this individual-tree level approach were very similar to those obtained in the initial exploratory analyses using all point-level data.

Estimates of the corewood, outerwood and transition wood limits for each wood property and site were calculated using the models derived from the site-level parameters (models 1-3 above). The threshold used for determining the boundary of either the corewood or outerwood was the point where the modelled value of the wood property was, depending on trait, 
greater or less than 1 standard error from the relevant upper or lower asymptote. A corroboration of the boundaries was made through a visual inspection of the modelled curve, focusing on identifying the point where the changes in wood properties stabilised consistent with the presence of corewood or outerwood according to the typical radial pattern of the majority of forest tree species (Lachenbruch et al. 2011; Moore and Cown 2017).

For MOE, the ages at which the modelled values exceed a threshold of $14 \mathrm{GPa}$ were identified to indicate the age at which veneer suitable for structural purposes could be recovered. This threshold was selected based on a previous study of MOE in Tasmanian E. nitens (MOE estimated via sonic resonance, with a similar calibration procedure of SilviScan). This study showed that veneer with $>14 \mathrm{GPa}$ produced premium structural plywood and LVL (Blackburn et al. 2018a). Thus, this threshold was estimated using the individual-tree and site models. Using the tree-level data, one-way ANOVAs were fitted with the PROC GLM procedure of $\mathrm{SAS}^{\mathrm{TM}}$ (version 9.4; SAS Institute, Cary, NC, USA) to compare site differences in pith-zone values $(Y=0)$ and the age at which wood over $14 \mathrm{GPa}$ is produced, both weighted by the inverse of their standard error. Pearson correlations were calculated to establish if there was a significant relationship of the mean MOE with the cambial age at which the threshold was reached (earlier the better).

In addition to the modelling of radial trends described above, two additional analyses were performed on the SilviScan data to compare the variation in wood density, MFA and MOE among the study sites. The first analysis compared sites based on unweighted and weighted disk means (Appendix 2). The second analysis compared the differences between inner and outer samples at each site (Appendix 3).

\section{Results}

\subsection{Models of the patterns of radial change across sites}

\subsubsection{Wood density}

Both the linear and four-parameter logistic models consistently converged when modelling the radial variation in wood density, but the four-parameter logistic model was selected as the AIC was lower in all comparisons (Table 3). Using tree-level data, the asymptote of the corewood and the outerwood asymptote differed significantly among sites $(P<0.01$ and $P<0.05$, respectively; Table 4$)$. The least productive site (Strathblane) had the highest wood density of the corewood (i.e. Asym core$_{\text {) }}$ ) but, as noted above, exhibited less radial change (lower scal) than the more productive sites although the difference was not statistically significant ( $P \geq 0.05$; Fig. 2 , Table 4$)$. Early-age comparisons among sites in wood density were not indicative of differences in corewood density, but the wood density of outerwood was higher at Geeveston than that at the Strathblane site (i.e. larger Asym ${ }_{\text {outer }}$ values in Table 4).

The model fitted predicted a relatively stable phase of wood density through the corewood, as evidenced by the period over which wood density did not deviate markedly (1 SE) from the corewood asymptote $\left(\right.$ Asym $_{\text {core }}$; Fig. 2). At this height in the stem $(2.5 \mathrm{~m})$, this corewood period persisted for 6 years at the more productive sites (Geeveston and Florentine) but extended to 8 years at the low-productivity Strathblane site (Fig. 2). Following a rapid increase in wood density during the transitional period, wood density stabilised in the outerwood, with this phase commencing at ring ages of between 11 and 13 years, being most delayed at the productive, thinned Geeveston site (Fig. 2).

\subsubsection{MFA}

As with wood density, both the linear and asymptotic exponential models consistently converged when modelling the radial variation in MFA, but the asymptotic exponential model was selected as the AIC was lower in all comparisons (Table 3). MFA was highest in the pith, but rapidly declined to an asymptote (Fig. 2). Sites did not differ in the MFA value at the pith (i.e. R0 ranged from 21.5 to $22.3^{\circ}$ ), but significant site differences were detected in the asymptote of the outerwood (i.e. Asym outer $_{\text {int }}$ ranged from 6.4 to $8.2^{\circ}$ ) and the pattern of curvature (lrc) describing the decrease between these values (Table 4). The most rapid decline in MFA towards the outerwood asymptote (i.e. lrc values approaching 0) was evident at Strathblane, followed by Geeveston and finally Florentine (Fig. 2). For example, the wood from the low-productivity site at Strathblane dropped to a $10^{\circ}$ MFA after 6 years of growth from the pith, while Geeveston and Florentine took 10 years and 9 years, respectively. The significant difference in outerwood asymptotes among sites was due to differences between the two more productive sites with Florentine stabilising at a lower MFA $\left(6.4^{\circ}\right)$ than Geeveston $\left(8.2^{\circ}\right)$. As unstable radial MFA values in conjunction with any sharp local variation in MFA would be conducive to differential longitudinal shrinkage and hence to dimensional instability, it is important to understand the point at which MFA reached a stable plateau in the stem. This is particularly relevant in veneer sheets after drying. Based on the site-level curves, it was estimated that the stable, outerwood phase for MFA began at ring ages from the pith of between 11 (Strathblane) and 19 years (Florentine) (Fig. 2).

\subsubsection{MOE}

A greater number of radial change models converged for MOE than for either wood density or MFA (Table 3). Both the linear 
Table 4 Model parameter means and standard errors (SE), $F$ ratios and the significance of differences among the means for three sampled sites for air-dry density (wood density), microfibril angle (MFA) and dynamic modulus of elasticity (MOE) as a function of cambial age

\begin{tabular}{|c|c|c|c|c|}
\hline \multirow[t]{2}{*}{ Wood property and parameters } & \multicolumn{3}{|l|}{ Cambial age } & \multirow[t]{2}{*}{$F_{2,22}$} \\
\hline & $\begin{array}{l}\text { Strathblane } \\
\text { Mean (SE) }\end{array}$ & $\begin{array}{l}\text { Geeveston } \\
\text { Mean (SE) }\end{array}$ & $\begin{array}{l}\text { Florentine } \\
\text { Mean (SE) }\end{array}$ & \\
\hline \multicolumn{5}{|l|}{ Wood density $\left(\mathrm{kg} \mathrm{m}^{-3}\right)$} \\
\hline Asym $_{\text {core }} 1$ & $562.0^{\mathrm{a}}(8.4)$ & $523.0^{\mathrm{b}}(8.6)$ & $520.0^{\mathrm{b}}(7.2)$ & $8.2 * *$ \\
\hline Asym $_{\text {outer }}{ }^{2}$ & $668.1^{\mathrm{ab}}(23.4)$ & $704.5^{\mathrm{a}}(21.3)$ & $619.6^{\mathrm{b}}(18.7)$ & $4.6^{*}$ \\
\hline $\mathrm{Xmid}^{3}$ & $10.5^{\mathrm{a}}(0.9)$ & $10.2^{\mathrm{a}}(0.7)$ & $9.0^{\mathrm{a}}(0.8)$ & $1.1^{\mathrm{ns}}$ \\
\hline $\mathrm{scal}^{4}$ & $0.8^{\mathrm{a}}(0.3)$ & $1.3^{\mathrm{a}}(0.3)$ & $1.1^{\mathrm{a}}(0.3)$ & $0.8^{\mathrm{ns}}$ \\
\hline $\operatorname{RMSE}^{5}\left(\mathrm{~kg} \mathrm{~m}^{-3}\right)$ & 24.8 & 19.8 & 21.6 & \\
\hline \multicolumn{5}{|l|}{ MFA (degrees) } \\
\hline Asym $_{\text {outer }}^{2}$ & $7.9^{\mathrm{ab}}(0.5)$ & $8.2^{\mathrm{a}}(0.6)$ & $6.4^{\mathrm{b}}(0.4)$ & $4.3 *$ \\
\hline$R 0^{6}$ & $21.5^{\mathrm{a}}(1.2)$ & $22.3^{\mathrm{a}}(1.1)$ & $22.2^{\mathrm{a}}(0.8)$ & $0.1^{\mathrm{ns}}$ \\
\hline $\operatorname{lrc} c^{7}$ & $-1.0^{\mathrm{a}}(0.1)$ & $-1.4^{\mathrm{ab}}(0.1)$ & $-1.5^{\mathrm{b}}(0.1)$ & $5.8 * *$ \\
\hline $\operatorname{RMSE}^{5}$ (degrees) & 1.9 & 1.6 & 2.1 & \\
\hline \multicolumn{5}{|l|}{ MOE (GPa) } \\
\hline Asym $_{\text {outer }}^{2}$ & $18.7^{\mathrm{a}}(1.5)$ & $20.0^{\mathrm{a}}(1.5)$ & $22.2^{\mathrm{a}}(1.7)$ & $1.2^{\mathrm{ns}}$ \\
\hline $\mathrm{Xmid}^{3}$ & $0.8^{\mathrm{a}}(0.8)$ & $2.5^{\mathrm{ab}}(0.8)$ & $3.8^{\mathrm{b}}(0.8)$ & $3.6^{*}$ \\
\hline $\mathrm{scal}^{4}$ & $3.4^{\mathrm{a}}(0.5)$ & $4.4^{\mathrm{ab}}(0.5)$ & $5.8^{\mathrm{b}}(0.5)$ & $5.9 * *$ \\
\hline $\operatorname{RMSE}^{5}(\mathrm{GPa})$ & 1.1 & 1.0 & 1.0 & \\
\hline
\end{tabular}

A four-parameter logistic model was fitted for wood density, an asymptotic exponential model for MFA and a three-parameter logistic model for MOE. Sites with common letters are not significantly different for the parameter indicated

${ }^{\text {ns }} P \geq 0.05 ; * P<0.05 ; * * P<0.01$

${ }^{1}$ Asymptote for corewood

${ }^{2}$ Asymptote for outerwood

${ }^{3}$ Age in years at which the inflection point of the curve occurs

${ }^{4}$ Slope at the inflection point of the curve

${ }^{5}$ RMSE root mean square error

${ }^{6} Y$ intercept

${ }^{7}$ Natural logarithm of the rate of curvature and the three-parameter logistic sigmoidal functions converged when modelling MOE, but the three-parameter logistic sigmoidal function model was selected as the AIC was lower compared to the linear and most other converged models (Table 3 ). This model described an increase in MOE with age to an asymptotic value (Fig. 2). The maximum outerwood asymptotic values for MOE ranged from 18.8 to $22.2 \mathrm{GPa}$, but these site differences were not significant (Table 4). However, there were highly significant differences among sites in the other two parameters (Xmid and scal), indicating age in years at which the inflection point of the curve occurs and slope at the inflection point of the curve, respectively. The lower-productivity site, Strathblane, clearly exhibited the most abrupt increase in MOE; however, there were no major visual differences among the other two sites (Fig. 2, Table 4).

The cambial age at which wood was produced with MOE over the 14-GPa threshold for structural uses was substantially earlier at Strathblane than the other two sites, with a significant difference among sites in the age at which this threshold was reached $\left(F_{2,22}=8.4 ; P=0.003\right)$. The low-productivity Strathblane site reached this threshold at the age of 4.1 years old, more than 2 years and 3 years earlier than the Geeveston (6.3-year-old) and Florentine (7.1-year-old) sites, respectively (Fig. 2). Similarly, the predicted MOE at the pith was significantly different among sites (intercept $X=0 ; F_{2,22}=7.6 ; P=$ $0.03)$, with the highest values $(8.7 \mathrm{GPa})$ occurring at the Strathblane site (Fig. 2). At the tree level, across all sites, the age at which the threshold MOE of $14 \mathrm{GPa}$ was surpassed was negatively correlated with the weighted mean $\operatorname{MOE}(n=25 ; r=$ $-0.67 ; P<0.001$ ), indicating that the earlier the threshold was crossed, the greater the average MOE of the tree. Accordingly, the site rankings were the same for weighted mean MOE (Strathblane $>$ Geeveston $>$ Florentine; Table 6 in Appendix 2) and years of growth with MOE above the threshold (Fig. 2).

While the outerwood asymptotes for MOE were not statistically different among sites, there were clearly large site differences in the age at which stable MOE was achieved, which followed the relative site differences mentioned above for 
Strathblane Site
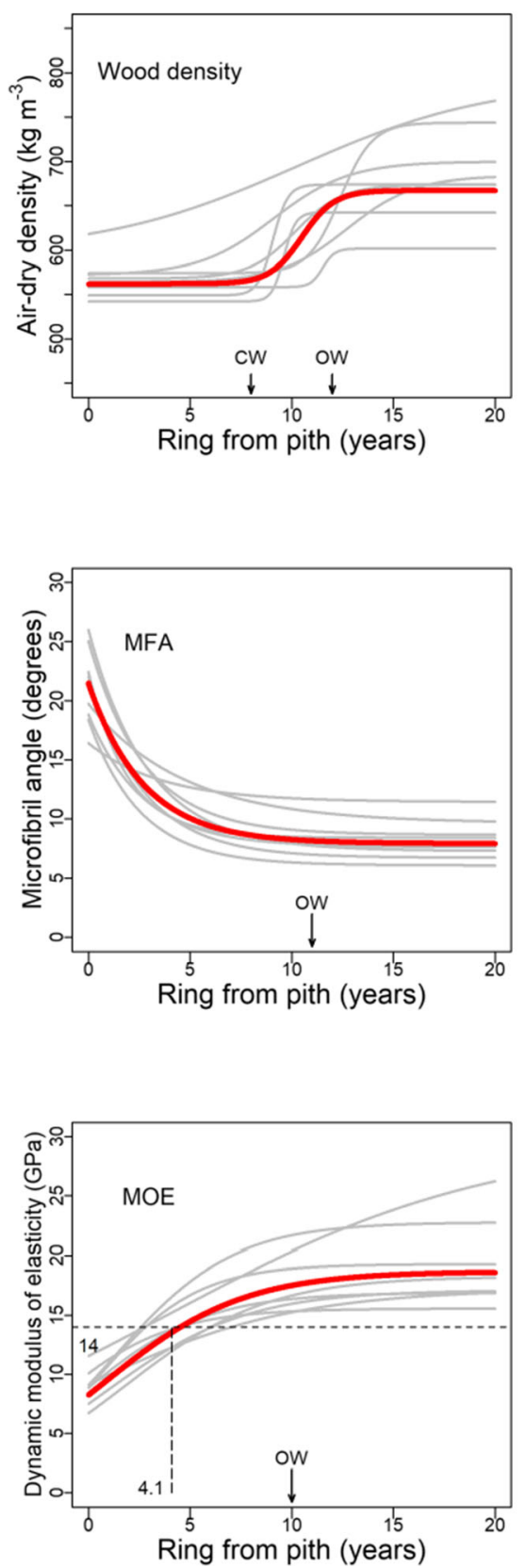

Fig. 2 The fitted models for each tree (grey line) and site (red line) for airdry density (wood density), microfibril angle (MFA) and dynamic modulus of elasticity (MOE) as a function of cambial age. The MOE threshold of $14 \mathrm{GPa}$ is also shown along with the age at which this threshold is
Geeveston Site
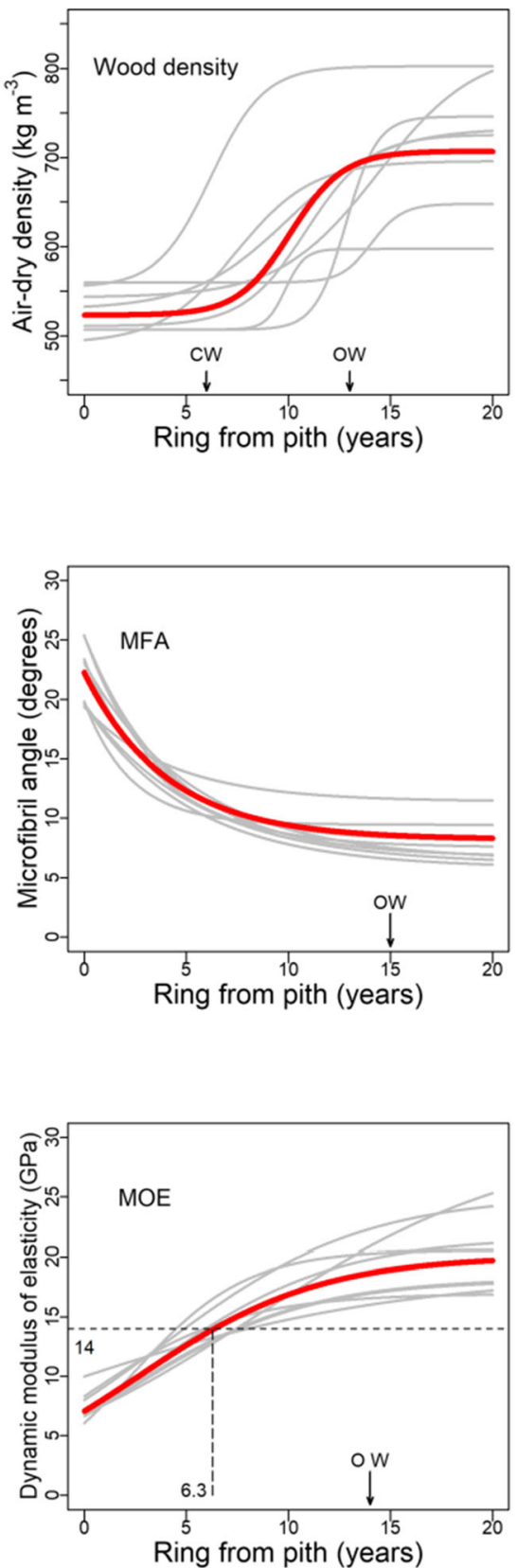

Florentine Site
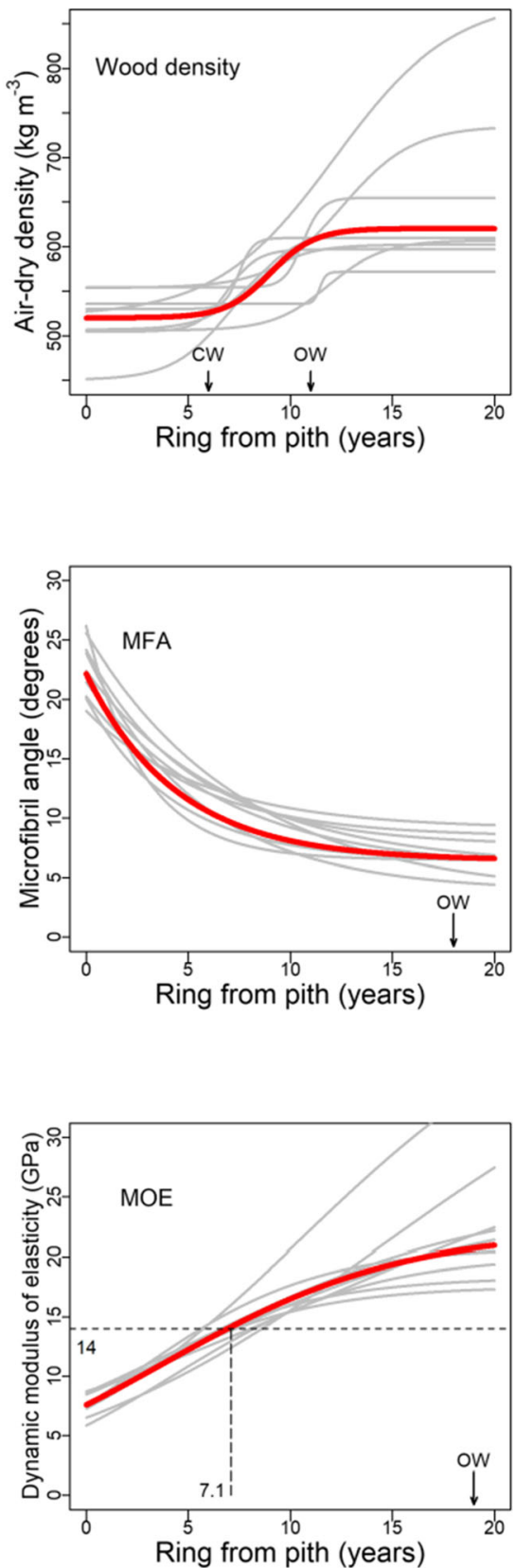

reached (dashed lines). Arrows indicate the outer boundary of corewood $(\mathrm{CW})$ and the inner boundary of outerwood (OW) for wood density, and for MFA and MOE, the arrows only indicate the inner boundary of outer wood, with the limits indicated specific to each wood property

reaching the 14-GPa MOE threshold. However, the cambial age at which stable MOE values were first achieved varied markedly ranging from 10 years (Strathblane) to 19 years (Florentine) (Fig. 2). Indeed, the earlier cambial age at which outerwood commenced also coincided with increased stability in wood properties (i.e. wood density at 12 years, MFA at 11 years and MOE at 10 years for Strathblane; Fig. 2). The transitional stage was also shorter at the Strathblane site and longest at Geeveston. Our modelling suggests that at the site level, the minimal cambial age for producing outerwood, where all three wood properties have reached their outerwood asymptote and stabilised, is 10 years (Strathblane), but this age for universal stability may extend up to 19 years, as is the case predicted for the Florentine site.

Neither the conventional disk mean (unweighted) nor weighted disk means significantly differed among sites for wood density, MFA and MOE (Appendix 2). At each site, 
all wood properties exhibited a significant difference between inner and outer samples ( $t$ test from zero; $P<0.05$ ) (Appendix 3). The wood density and MOE of the outer samples were higher than those of the inner samples, and MFA was lower. These trends were the same at all sites, but in some cases, the magnitude of the change differed.

\section{Discussion}

The current study revealed differences in wood density, MFA and MOE between inner and outer samples of $E$. nitens, consistent with corewood and outerwood differences reported in other eucalypt species (Downes et al. 2014; Lima et al. 2004). These differences involve an increase in wood density and MOE and a decrease in MFA with age (Downes et al. 2014; Hein and Brancheriau 2011; Medhurst et al. 2012; Salvo et al. 2017). While our study was based on samples collected at $2.5 \mathrm{~m}$ aboveground level, studies of within-tree variation in E. nitens wood properties suggest that these radial trends persist along the stem with respect to the ring number from the cambium (Downes et al. 1997). While these radial trends were evident from a simple comparison of inner and outer samples and despite modelling only eight to nine trees per site, our detailed study of radial change showed that the traits and sites differed in their pattern of change in wood properties over the 20- to 22-year timeframe studied.

\subsection{Wood density}

Radial variation in wood density was appropriately described by the four-parameter logistic model. These sigmoid-type models have also been reported in conifers such as Pseudotsuga menziesii (Mirb.) (Filipescu et al. 2014) and Pinus taeda L. (Mora et al. 2007), as well as other eucalypts including E. nitens (McGavin et al. 2015). Our results are also consistent with visual plots of the radial variation of wood density in other eucalypts, including E. nitens (Medhurst et al. 2012; Salvo et al. 2017). With 10-year-old Eucalyptus globulus Labill., Downes et al. (2014) modelled radial change in wood density using simple linear regression models but this age span is prior to the transition to outerwood in the present study. In older trees, the four-parameter logistic model thus appears more appropriate as it describes the transition from low-density corewood to higher-density outerwood. This transition commences just after 6 years of age, which is 2-4 years after the normal timing of heteroblastic transition in leaf morphology (Williams et al. 2004), suggesting these are independent changes.

The model fitted for wood density showed that site differences were due to differences in both corewood density $\left(\right.$ Asym $\left._{\text {core }}\right)$ and outerwood density $\left(\right.$ Asym $\left._{\text {outer }}\right)$. The highest corewood density was found for trees grown at Strathblane which could be a consequence of unfavourable site growth conditions (lowest site index) in the early stage of the plantation. Such conditions could reduce vessel area and increase cell wall thickness, resulting in higher wood density (Downes and Drew 2008; Lachenbruch et al. 2011; Zobel and van Buijtenen 1989). The opposite situation would therefore apply at Florentine, which had the lowest wood density and was considered a good-quality site. Geeveston had the highest growth rate of our sites as well as the highest rate of radial increase in wood density, but there were no detectible differences among sites in the rate of radial increase.

\subsection{MFA}

An asymptotic exponential model appropriately represented the radial trend in MFA, revealing a rapid drop during the first years followed by a less rapid decrease, consistent with previous studies in eucalypts (Evans et al. 2000; Hein and Brancheriau 2011; Medhurst et al. 2012). While no fine-scale modelling of radial variation in MFA was found for eucalypts, conifers exhibit the same trend (Donaldson 2008). In this case, the main models used for MFA are logistic models, fitted as a function of ring number from the pith (Jordan et al. 2005; Moore et al. 2014). However, such models were not successful in our study (Table 3). This may be due to the greater radial change in conifer MFA values. According to Donaldson (2008), conifers vary more than hardwoods, with drops in values from ca. 45to $11^{\circ}$ in comparison with, for example, E. nitens where MFA in the study dropped from ca. 22 to $8^{\circ}$.

For MFA, the asymptotic exponential model showed pith values similar to those reported by Medhurst et al. (2012) in 22-year-old $E$. nitens, but slightly higher than those found by Evans et al. (2000) for 15-year-old E. nitens. Outerwood asymptote values in these previous studies, however, were notably higher than reported here. This difference could be a consequence of the height of sampling, as shown by Evans et al. (2000) and Medhurst et al. (2012) who sampled at the DBH height of $1.3 \mathrm{~m}$, whereas the samples in the present study were taken at $2.5 \mathrm{~m}$. The significant differences among sites for the outerwood asymptote or pith values of MFA in our study agrees with results from Lima et al. (2004), who reported site effects on outerwood values but not on the pithzone values. Lima et al. (2004) studied clones of Eucalyptus grandis $\times$ Eucalyptus urophylla growing in the warm climate of Brazil and reported a genetic influence on MFA, but it is not clear whether genetics or site had the greater influence.

In the current study, the Strathblane plantation was established on a poor-quality site, with DBH $(31.2 \mathrm{~cm})$ significantly lower than that observed at Geeveston $(42.7 \mathrm{~cm})$ despite a very similar silvicultural treatment. However, MFA values at Strathblane reached a stable outerwood state earlier than Geeveston, and a greater proportion of the wood had low MFA. Wimmer et al. (2002) found a positive relationship between growth rate and MFA in E. nitens, so factors that influence growth rate could also affect the rate of decline in MFA from pith 
to cambium. This pattern observed by Wimmer et al. (2002) is consistent with our observations at Strathblane. On the other hand, Geeveston and Florentine had very different silviculture treatments but similar site quality. Geeveston exhibited the largest DBH, presumably due to thinning, but a slightly (yet significantly) lower rate of decline in MFA than at Florentine. Of the sites studied, Geeveston had the greatest exposure to wind which, in conjunction with thinning, would produce a higher risk of stems breaking. According to Lachenbruch et al. (2011), trees need to increase wood stiffness with age/size to avoid stem fracture due to self-weight and wind. As high stiffness is highly correlated with low values of MFA, a decrease in MFA value would increase stiffness (Donaldson 2008; Lachenbruch et al. 2011). Thus, under this hypothesis, Geeveston trees would be expected to produce lower MFA values earlier than Florentine to increase their stiffness in response to higher wind exposure. The extent to which such effects could be confounded with increasing prevalence of tension wood (which has low MFA) is unclear; however, no relationship between MFA and tension wood has been reported in either E. globulus or E. nitens in processing studies (Washusen et al. 2001).

\subsection{MOE}

For MOE, the radial change was best described using a threeparameter logistic model, which accords with the general trends found in previous studies of E. nitens (Harwood et al. 2005; Medhurst et al. 2012). McGavin et al. (2015) also used a logistic function to model the trends but with four parameters. The shape of the logistic function is consistent with the structural integrity theory in trees, as described by Lachenbruch et al. (2011). That is, lower MOE in early-stage growth (core wood) increases stem flexibility and thus allows young trees to bend with external forces like wind and snow. As the trees increase in age, however, the stems require increasing stiffness to avoid failure due to environmental factors and their own weight. At a certain stiffness value, the progression stops, and stiffness remains relatively constant (approaching asymptote), which is believed to help distribute the bending stress produced by environmental factors, especially wind, over a large sectional area (Lachenbruch et al. 2011; McGavin et al. 2015).

The sigmoid model evaluating the modulus of elasticity showed that outerwood asymptotic values of MOE did not differ statistically among sites, with an average of $19.4 \mathrm{GPa}$ across sites. This average asymptote of the outerwood is 19\% larger than that reported by McGavin et al. (2015) using sample strips of veneers obtained from logs from the same trees as the current study, presumably due to differences in sampling protocols. McGavin et al. (2015) measured dynamic MOE using sonic resonance and strip samples from the veneer, cut parallel to the grain between 0.5 and $2.5 \mathrm{~m}$ above the ground, which may have included natural defects, whereas the
SilviScan estimates of MOE were measured using clearwood samples obtained at a height of $2.5 \mathrm{~m}$.

The lack of difference among sites in the MOE asymptote of the outerwood could be associated with phenotypic stability of the outerwood zone. In contrast to the lack of differences in outerwood asymptote values, there were significant differences in the scale and inflection point parameters among sites for MOE. These parameters reflect the rate of radial change in the trees. Day and Greenwood (2011) considered that radial development is controlled by both intrinsic (gene expression) and extrinsic (environmental) factors. However, the same authors recognised that it is very difficult to determine which is most influential. In a study of outerwood MOE and wood density in Pinus radiata D. Don, a greater influence of site and silviculture than genetics has been shown (Carson et al. 2014; McLean et al. 2016). Although $P$. radiata is not directly comparable with Eucalyptus spp. and such comparisons will depend upon the range of genetic and site treatments compared, they provide an indication of the influence extrinsic factors can have on forest plantations. In the present study, the sites differed in silviculture and environments but there is no precise information about genetic stock. However, most Tasmanian E. nitens plantations established approximately 20 years ago were from naturalstand seed collections from Central Victoria (Hamilton and Potts 2008). Thus, the similar MOE asymptote could reflect the similar genetic stock reaching the same value across a range of growing conditions and silviculture studied, but these site factors only affect the rate at which the asymptote is achieved.

\section{Conclusion}

In conclusion, our models revealed a dynamic change in wood properties across the stem radius of $E$. nitens trees, with the pattern varying with trait and the plantations studied. Plantations differed in the age and proportion of the stem where wood properties have stabilised and reached accepted threshold values of stiffness suitable for products such as structural plywood. The models suggest an outerwood phase is reached where site average values for all three wood properties studied have reached asymptotic values. This phase is reached at cambial age of between 10 and 19 years, with the faster-growing plantations taking longer. The relatively stable outerwood phase is preceded by a phase of wood production where wood density is initially low and stable but MFA is rapidly decreasing, but then as MFA starts to stabilise, wood density rapidly increases. Thus, while a stable phase of corewood may be evident for wood density, this is not generally applicable as other traits such as MFA and MOE are changing rapidly in the corewood.

Acknowledgements We acknowledge Sustainable Timber Tasmania (former Forestry Tasmania) for assistance in project planning, access to sites, the provision of trees and staff, tree felling and disks preparation.

\section{פ̂s Spriger INRAC}


Specifically, we thank: Paul Adams (former FT Senior Research Scientist \& Principal Scientist Research); Chris Emmett (IST); Peter Wass, Crispen Marunda, Kristen Dransfield, Matt McCormic, Mitchell Fulford, Rowan Eiszele and Shane Burgess. We also thank CSIRO Land and Water for access to the laboratories and facilities, David Blackburn for field assistance and valued discussion, Chris Harwood for his suggestions and advice in the early stage of this research, and Mark Hunt from the ARC Training Centre for Forest Value for the continuing support of this research.

Funding Information MV was supported by the Advanced Human Capital Program - CONICYT (Becas Chile) from the Chilean Government and a top-up from the Australian Cooperative Research Centre for Forestry. Research funding for the project was provided by The National Centre for Future Forest Industries (NCFFI) and ARC Training Centre for Forest Value (grant number IC150100004) at the University of Tasmania.

Data availability The datasets generated during and/or analysed during the current study are available from the corresponding author on reasonable request.

\section{Appendix 1. Testing the difference between trees within sites}

Table 5 Significance of the differences in radial models among trees within sites (intra-site) for wood density, microfibril angle (MFA) and modulus of elasticity (MOE) as a function of cambial age

\begin{tabular}{llll}
\hline Wood property & \multicolumn{3}{l}{ Sites } \\
\cline { 2 - 4 } & Strathblane & Geeveston & Florentine $^{(1)}$ \\
& $F_{21-28,114-143}$ & $F_{21-28,124-132}$ & $F_{24-28,130-137}$ \\
\hline Wood density & $2.4^{* * *}$ & $9.3 * * *$ & $4.9 * * *$ \\
MFA & $5.9^{* * *}$ & $6.2^{* * *}$ & $9.4^{* * *}$ \\
MOE & $9.0^{* * *}$ & $9.0^{* * *}$ & $16.0^{* * *}$ \\
\hline
\end{tabular}

The $F$ values and their significance for each site and model are shown. A four-parameter logistic model was fitted for wood density, an asymptotic exponential model for microfibril angle and a three-parameter logistic sigmoidal model for modulus of elasticity

$* * * P<0.001$

${ }^{(1)}$ One tree did not converge for wood density using nls function
Appendix 2. Analyses based on tree means

\section{Methods}

Unweighted disk means of wood properties were estimated as the averages of the ring wood property values from disk. Additionally, disk means were estimated by weighting ring means by ring area (weighted disk means), to allow a more accurate representation of the tree-level wood property means (Downes et al. 1997). This methodology assumed that rings were circular and that there was no pith eccentricity. The methodology of Medhurst et al. (2011) was used to quantify eccentricity to test this assumption. Using this measure for each tree, a one-way ANOVA was used to test the differences among the study sites using the anova function of $\mathrm{R}(\mathrm{R}$ Development Core Team 2018).

\section{Results}

Neither the conventional means (unweighted) nor the weighted means significantly differed among sites for wood density, MFA and MOE (Table 6). While the study sites ranked similarly for MFA and MOE based on individual means (unweighted and weighted), wood density did not follow this trend. For example, when differences in wood density were assessed using unweighted means, Strathblane ranked highest for wood density; however, Geeveston ranked above Strathblane when using the weighted disk mean wood density (Table 6).

Disk eccentricity had an average of less than $10 \%$ for each site and did not differ among these sites $\left(F_{2,22}=1.1, P>0.05\right)$, arguing that the weighted means are a good estimate of the overall difference among sites. With the weighted mean values, wood density was lowest at Florentine but its site mean was not significantly different from Strathblane and Geeveston, according to a Tukey-Kramer multiple comparison test. Unweighted disk means were consistently lower than those based on the area weighted disk means

Table 6 Mean wood properties and significance of the differences among plantation sites of E. nitens

\begin{tabular}{|c|c|c|c|c|c|c|}
\hline \multirow[t]{2}{*}{ Site } & \multicolumn{2}{|c|}{ Wood density $\left(\mathrm{kg} \mathrm{m}^{-3}\right)$} & \multicolumn{2}{|c|}{ MFA (degrees) } & \multicolumn{2}{|l|}{$\operatorname{MOE}(\mathrm{GPa})$} \\
\hline & Unweighted & Weighted & Unweighted & Weighted & Unweighted & Weighted \\
\hline Strathblane & $596.9^{1}$ & $618.1^{2}$ & $11.5^{3}$ & $9.0^{3}$ & $14.7^{1}$ & $16.7^{1}$ \\
\hline Geeveston & $590.8^{2}$ & $626.4^{1}$ & $12.7^{2}$ & $9.9^{1}$ & $13.9^{2}$ & $16.4^{2}$ \\
\hline Florentine & $557.7^{3}$ & $577.1^{3}$ & $12.6^{1}$ & $9.8^{2}$ & $13.6^{3}$ & $15.9^{3}$ \\
\hline \multicolumn{7}{|c|}{ Significance of differences among sites } \\
\hline$F_{2,22}$ & 3.2 & 3.3 & 1.5 & 0.6 & 1.3 & 0.4 \\
\hline$P$ value & $0.06^{\mathrm{ns}}$ & $0.06^{\mathrm{ns}}$ & $0.25^{\mathrm{ns}}$ & $0.56^{\mathrm{ns}}$ & $0.28^{\mathrm{ns}}$ & $0.69^{\mathrm{ns}}$ \\
\hline
\end{tabular}

Results are presented based on unweighted and weighted disk mean values from samples taken $2.5 \mathrm{~m}$ aboveground level. All the site means were not significantly different $(P>0.05)$ among the sites according to the Tukey-Kramer multiple comparisons, so the superscript numbers denoted the site ranking 


\section{Appendix 3. Comparisons between inner and outer samples}

\section{Methods}

At a broad scale, the pith-to-cambium change in wood properties was investigated by comparing the inner (adjacent to the pith) and outer (adjacent to the cambium) samples from each tree, with the difference expressed as a percentage of the innermost sample. The samples were chosen as the two innermost and two outermost rings or, following Downes et al. (2014), the innermost and outmost $10 \%$ of cross-sectional area. Using this tree-level data, (i) a $t$ test was undertaken separately for each site and wood property to test the statistical significance from zero of the difference between the innermost and outermost samples, and (ii) a one-way ANOVA was undertaken to test for the difference in change among sites, with Tukey-Kramer multiple comparisons applied to compare site means. These analyses were undertaken using cambial age and percentage of area data for each wood property with the t.test and anova functions in $\mathrm{R}$ (R Development Core Team 2018).

\section{Results}

At each site, all wood properties exhibited a significant difference between innerwood and outerwood ( $t$ test from zero; $P<0.05$ ). The wood density and MOE of outerwood were higher than those of innerwood (11.4 to $31.0 \%$ and 86.2 to $137.5 \%$ higher, respectively, depending upon site), and MFA was lower (-52.5 to $60.3 \%$ of inner sample), regardless of whether the ring or percentage area data as used (Table 7).

Sites did not differ significantly in the magnitude of the difference in MFA and MOE between innerwood and
Table 7 Site means for the difference between pith and cambium samples for wood density, microfibril angle (MFA) and modulus of elasticity (MOE)

\begin{tabular}{|c|c|c|c|c|c|c|}
\hline \multirow[t]{2}{*}{ Site } & \multicolumn{2}{|c|}{$\begin{array}{l}\text { Wood density } \\
\left(\mathrm{kg} \mathrm{m}^{-3}\right)\end{array}$} & \multicolumn{2}{|c|}{ MFA (degrees) } & \multicolumn{2}{|c|}{$\operatorname{MOE}(\mathrm{GPa})$} \\
\hline & Rings & Percentage & Rings & Percentage & Rings & Percentage \\
\hline Strathblane & $11.4 \mathrm{a}$ & $11.6 \mathrm{a}$ & $-53.3 \mathrm{a}$ & $-52.5 \mathrm{a}$ & 89.9 a & $86.2 \mathrm{a}$ \\
\hline Geeveston & $24.5 \mathrm{a}$ & $31.0 \mathrm{~b}$ & $-59.1 \mathrm{a}$ & $-56.8 \mathrm{a}$ & $131.6 \mathrm{a}$ & $134.0 \mathrm{a}$ \\
\hline Florentine & $19.5 \mathrm{a}$ & $20.3 \mathrm{ab}$ & $-60.3 \mathrm{a}$ & $-58.2 \mathrm{a}$ & $137.5 \mathrm{a}$ & $134.0 \mathrm{a}$ \\
\hline \multicolumn{7}{|c|}{ Significance of differences among sites } \\
\hline$F_{2,22}$ & 2.0 & 6.1 & 0.7 & 0.4 & 1.9 & 2.2 \\
\hline$P$ value & $0.16^{\mathrm{ns}}$ & $0.008 * *$ & $0.52^{\mathrm{ns}}$ & $0.69^{\text {ns }}$ & $0.17^{\mathrm{ns}}$ & $0.14^{\mathrm{ns}}$ \\
\hline
\end{tabular}

The differences were between the two innermost rings and the two outermost rings expressed as a percentage of the innermost rings. Site means significantly different $(P<0.05)$ according to a Tukey-Kramer multiple comparison test are denoted by different letters. ns $P \geq 0.05 ; * * \mathrm{P}<0.01$

outerwood, and only when expressed in terms of percentage was there a significant difference for wood density $(P<0.05)$. Wood density of Geeveston and Strathblane had the greatest and smallest difference between the innermost and outermost wood, respectively.

The rank order of sites and the magnitude of the change in all response variables remained the same, regardless of how the comparison was made and whether sites were significantly different. In wood density, Strathblane showed the least change between pith and cambium, followed by Florentine and Geeveston. On the other hand, Strathblane continued showing the least change, but followed by Geeveston instead of Florentine (Table 7).

\section{Appendix 4. Summary of wood properties by site}

Table 8 Summary of wood properties measured using SilviScan by site

\begin{tabular}{|c|c|c|c|c|c|c|c|c|c|}
\hline \multirow[t]{2}{*}{ Statistics } & \multicolumn{3}{|c|}{ Wood density $\left(\mathrm{kg} \mathrm{m}^{-3}\right)$} & \multicolumn{3}{|c|}{ MFA (degrees) } & \multicolumn{3}{|l|}{$\operatorname{MOE}(\mathrm{GPa})$} \\
\hline & Strathblane & Geeveston & Florentine & Strathblane & Geeveston & Florentine & Strathblane & Geeveston & Florentine \\
\hline$n$ & 8.0 & 8.0 & 9.0 & 8.0 & 8.0 & 9.0 & 8.0 & 8.0 & 9.0 \\
\hline Mean & 596.9 & 590.8 & 557.7 & 11.5 & 12.7 & 12.6 & 14.7 & 13.9 & 13.6 \\
\hline SD & 34.4 & 41.6 & 27.3 & 1.8 & 1.4 & 1.5 & 1.9 & 1.2 & 1.3 \\
\hline Median & 592.7 & 585.2 & 556.7 & 11.6 & 12.3 & 13 & 13.9 & 14 & 13.5 \\
\hline SE & 12.1 & 14.7 & 9.1 & 0.6 & 0.5 & 0.5 & 0.7 & 0.4 & 0.4 \\
\hline Min & 569.4 & 540 & 515.1 & 8.8 & 11.2 & 10.2 & 12.9 & 12 & 11.9 \\
\hline Max & 676.5 & 683.5 & 604.6 & 13.6 & 15.1 & 14.7 & 18.2 & 15.4 & 16.1 \\
\hline Range & 107.1 & 143.5 & 89.5 & 4.7 & 3.9 & 4.4 & 5.3 & 3.4 & 4.2 \\
\hline
\end{tabular}

All data are unweighted (core means) and based on individual tree data 
Table 9 Summary of wood properties measured using SilviScan by site. All data are weighted by the area of the disk and based on individual tree data.

\begin{tabular}{|c|c|c|c|c|c|c|c|c|c|}
\hline \multirow[t]{2}{*}{ Statistics } & \multicolumn{3}{|c|}{ Wood density $\left(\mathrm{kg} \mathrm{m}^{-3}\right)$} & \multicolumn{3}{|c|}{ MFA (degrees) } & \multicolumn{3}{|l|}{$\operatorname{MOE}(\mathrm{GPa})$} \\
\hline & Strathblane & Geeveston & Florentine & Strathblane & Geeveston & Florentine & Strathblane & Geeveston & Florentine \\
\hline$n$ & 8.0 & 8.0 & 9.0 & 8.0 & 8.0 & 9.0 & 8.0 & 8.0 & 9.0 \\
\hline Mean & 618.1 & 626.4 & 577.1 & 9.0 & 9.9 & 9.8 & 16.7 & 16.4 & 15.9 \\
\hline SD & 38.8 & 53.1 & 34.5 & 2.0 & 1.7 & 1.6 & 2.3 & 1.7 & 1.8 \\
\hline Median & 618.9 & 622.1 & 575.1 & 9.0 & 9.9 & 10.4 & 15.7 & 16.4 & 15.4 \\
\hline SE & 13.7 & 18.8 & 11.5 & 0.7 & 0.6 & 0.5 & 0.8 & 0.6 & 0.6 \\
\hline Min & 576.3 & 556 & 537.5 & 6.2 & 8.1 & 7.4 & 14.6 & 14.2 & 14.4 \\
\hline Max & 700.1 & 741.7 & 651 & 11.8 & 12.9 & 11.4 & 20.7 & 18.6 & 20.2 \\
\hline Range & 123.8 & 185.7 & 113.5 & 5.6 & 4.8 & 4.0 & 6.1 & 4.3 & 5.8 \\
\hline
\end{tabular}

\section{Appendix 5. Models selected at site level data}

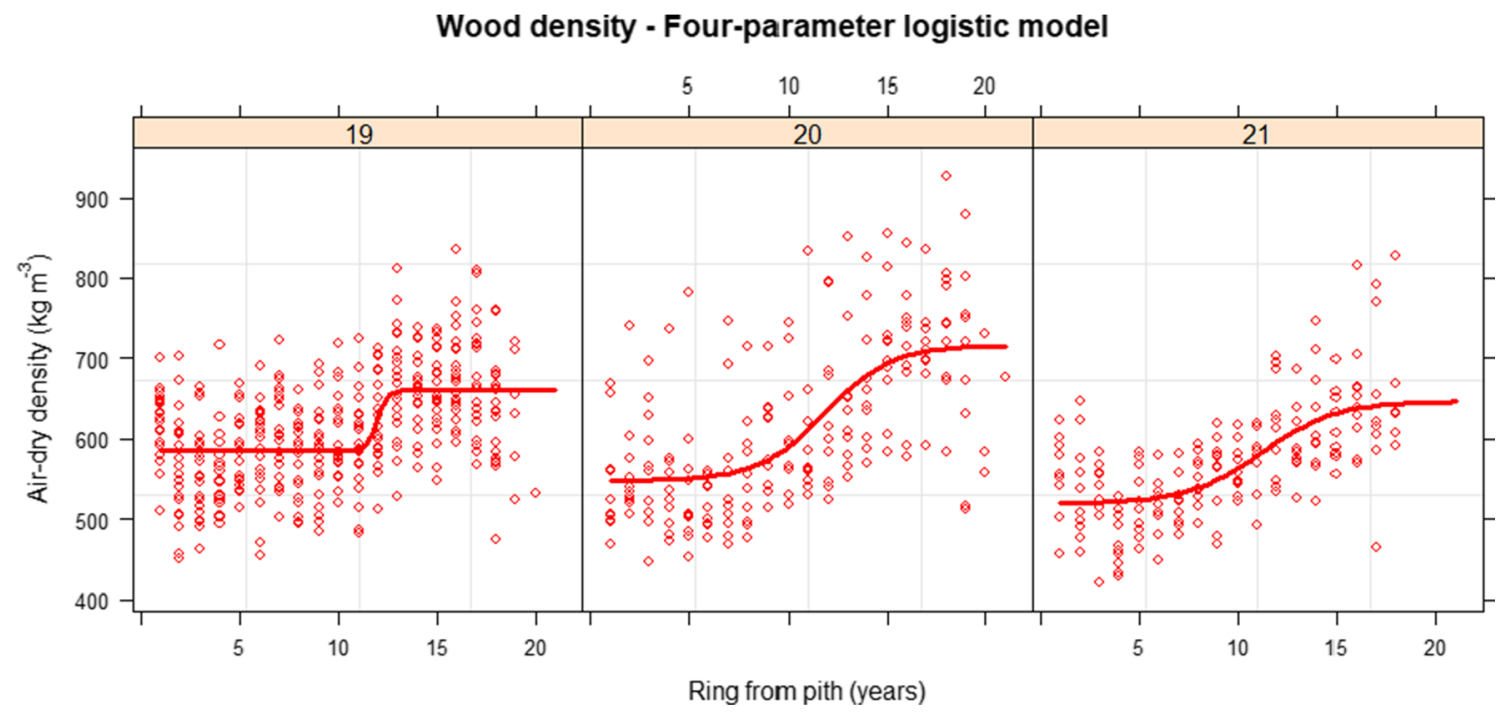

Fig. 3 Selected wood density models for cambial age using pooled data by site and wood property (19, Strathblane; 20, Geeveston; 21, Florentine)

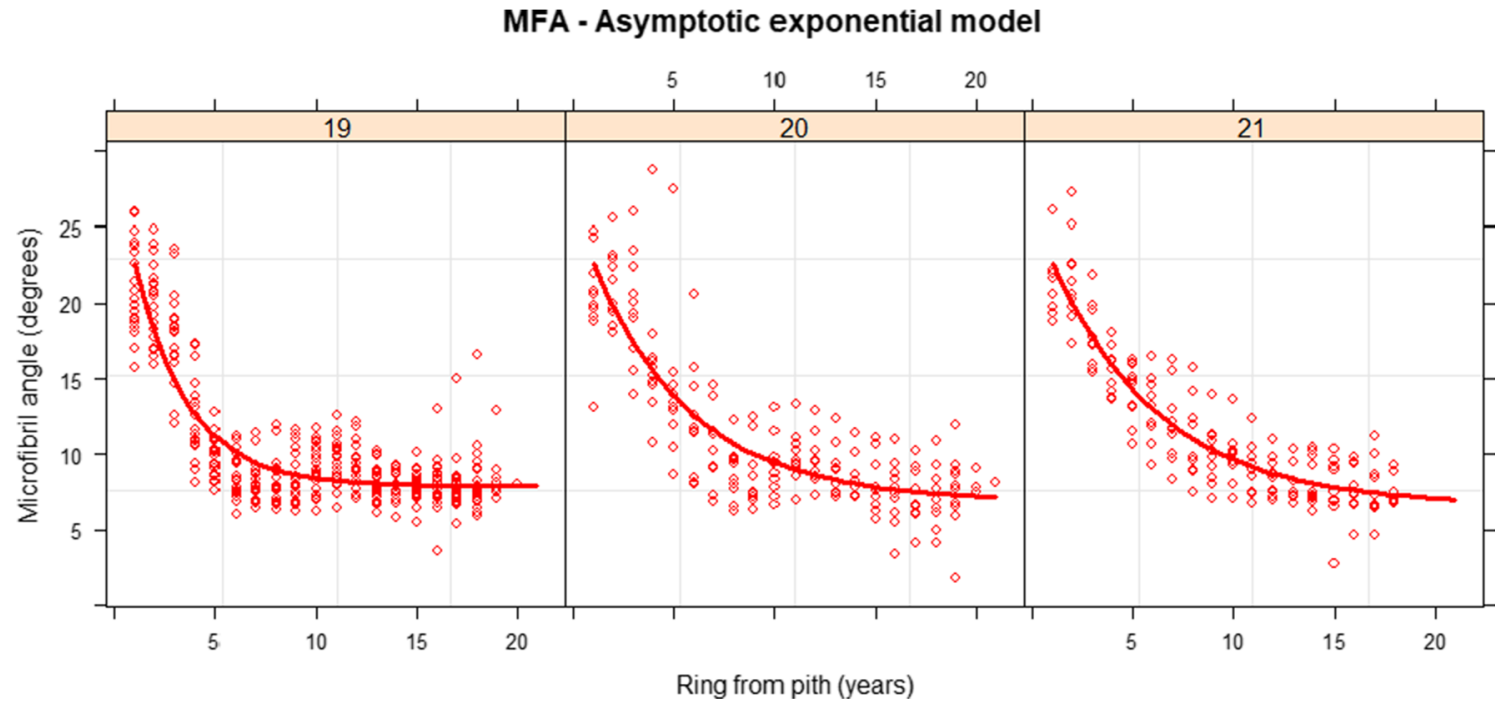

Fig. 4 Selected microfibril angle models for cambial age using pooled data by site and wood property (19, Strathblane; 20, Geeveston; 21, Florentine) 
MOE - Three-parameter logistic model

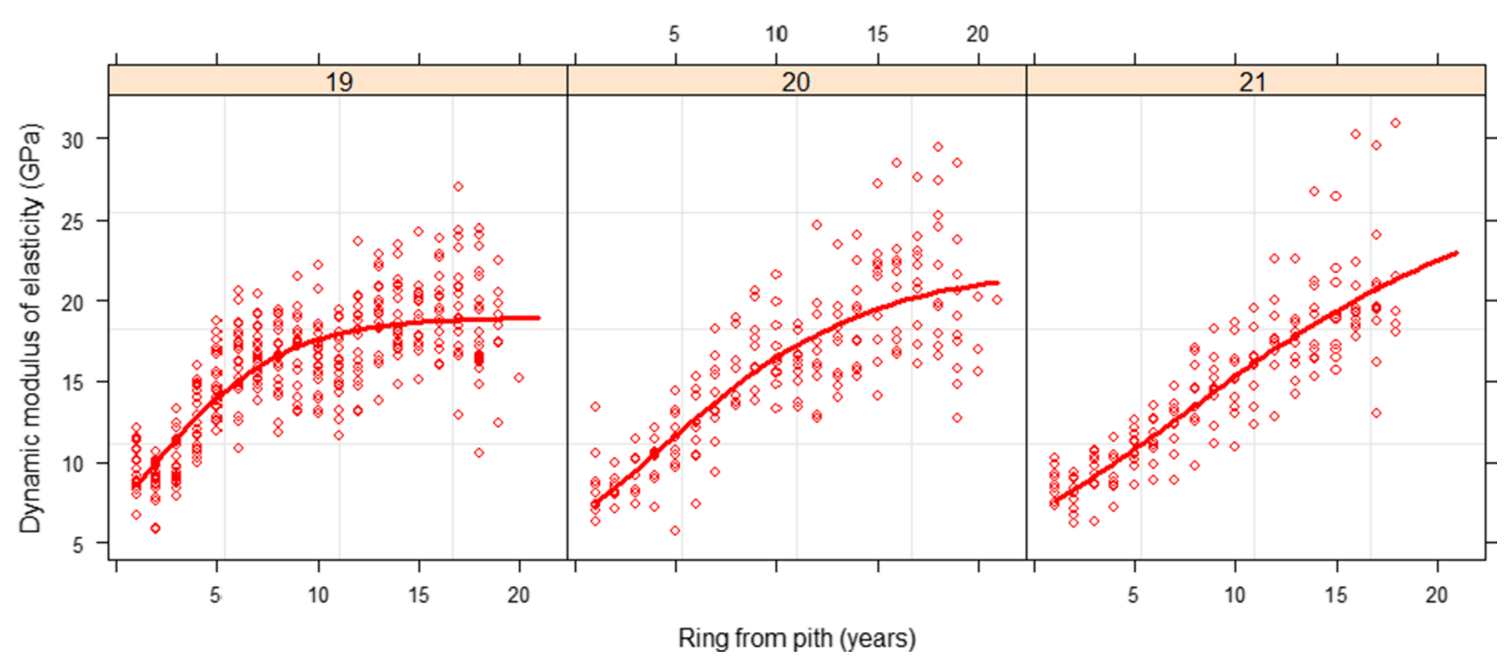

Fig. 5 Selected modulus of elasticity models for cambial age using pooled data by site and wood property (19, Strathblane; 20, Geeveston; 21, Florentine)

\section{References}

Akaike H (1974) A new look at the statistical model identification. IEEE Trans Autom Control 19:716-723. https://doi.org/10.1109/tac. 1974.1100705

Auty D, Achim A (2008) The relationship between standing tree acoustic assessment and timber quality in Scots pine and the practical implications for assessing timber quality from naturally regenerated stands. Forestry 81:475-487. https://doi.org/10.1093/forestry/ cpn015

Auty D, Gardimner BA, Achim A, Moore JR, Cameron AD (2013) Models for predicting microfibril angle variation in Scots pine. Ann Forest Sci 70:209-218. https://doi.org/10.1007/s13595-0120248-6

Auty D, Moore J, Achim A, Lyon A, Mochan S, Gardiner B (2018) Effects of early respacing on the density and microfibril angle of Sitka spruce wood. Forestry 91:307-319. https://doi.org/10.1093/ forestry/cpx004e

Barnett JR, Bonham VA (2004) Cellulose microfibril angle in the cell wall of wood fibres. Biol Rev 79:461-472. https://doi.org/10.1017/ s1464793103006377e

Blackburn D, Vega M, Yong R, Britton D, Nolan G (2018a) Factors influencing the production of structural plywood in Tasmania, Australia from Eucalyptus nitens rotary peeled veneer. South Forests 80:319-328. https://doi.org/10.2989/20702620.2017. 1420730

Blackburn D, Vega M, Nolan G (2018b) The potential to recover veneer based product from low grade native forest logs - PNB386-1516. Forest \& Wood Products Australia, Melbourne

Buehlmann U, Schuler A (2013) Markets and market forces for secondary wood products. In: Hansen E, Panwar R, Vlovsky R (eds) The global forest sector: changes, practices, and prospects. CRC

Burdon RD, Kibblewhite RP, Walker JCF, Megraw RA, Evans R, Cown DJ (2004) Juvenile versus mature wood: a new concept, orthogonal to corewood versus outerwood, with special reference to Pinus radiata and $P$. taeda. For Sci 50:399-415

Burkhart H, Tomé M (2012) Modeling wood characteristics. In: Modeling Forest trees and stands. Springer, Dordrecht, pp 405427. doi:https://doi.org/10.1007/978-90-481-3170-9_17

Carson SD, Cown DJ, McKinley RB, Moore JR (2014) Effects of site, silviculture and seedlot on wood density and estimated wood stiffness in radiata pine at mid-rotation. NZ J Forestry Sci 44:112. https://doi.org/10.1186/s40490-014-0026-3

Crawley MJ (2012) The R Book: Second Edition. John Wiley \& Sons, Ltd. https://doi.org/10.1002/9781118448908

Day ME, Greenwood MS (2011) Regulation of ontogeny in temperate conifers. In: Meinzer F, Lachenbruch B, Dawson T (eds) Size- and age-related changes in tree structure and function, vol 4. Springer, Tree Physiology, pp 91-119. https://doi.org/10.1007/978-94-0071242-3 4

Donaldson L (2008) Microfibril angle: measurement, variation and relationships - a review. Iawa J 29:345-386. https://doi.org/10.1163/ 22941932-90000192

Downes G, Drew D (2008) Climate and growth influences on wood formation and utilisation. South Forests 70:155-167. https://doi. org/10.2989/south.for.2008.70.2.11.539

Downes G, Hudson I, Raymond C, Dean G, Michell A, Schimleck L, Evans R, Muneri A (1997) Sampling plantation eucalypts for wood and fibre properties. CSIRO, Melbourne

Downes G, Harwood C, Washusen R, Ebdon N, Evans R, White D, Dumbrell I (2014) Wood properties of Eucalyptus globulus at three sites in Western Australia: effects of fertiliser and plantation stocking. Aust Forestry 77:179-188. https://doi.org/10.1080/00049158. 2014.970742

Downham R, Gavran M (2019) Australian plantation statistics 2019 update. ABARES, Canberra

Evans R (2006) Wood stiffness by X-ray diffractometry. In: Stokke DD, Groom LH (eds) Characterization of the cellulosic cell wall. Blackwell Publishing, Ames: Iowa State University Press, Iowa, pp 138-146

Evans R, Ilic J (2001) Rapid prediction of wood stiffness from microfibril, angle and density. Forest Prod J 51:53-57

Evans R, Stringer S, Kibblewhite RP (2000) Variation of microfibril angle, density and fibre orientation in twenty-nine Eucalyptus nitens trees. Appita J 53:450-457

Filipescu CN, Lowell EC, Koppenaal R, Mitchell A (2014) Modeling regional and climatic variation of wood density and ring width in intensively managed Douglas-fir. Can J For Res 44:220-229. https://doi.org/10.1139/cjfr-2013-0275

Gardiner B, Leban JM, Auty D, Simpson H (2011) Models for predicting wood density of British-grown Sitka spruce. Forestry 84:119-132. https://doi.org/10.1093/forestry/cpq050 
Hamilton M, Potts B (2008) Review of Eucalyptus nitens genetic parameters. NZ J Forestry Sci 38:102-119

Hamilton M, Dutkowski G, Joyce K, Potts B (2011) Meta-analysis of racial variation in Eucalyptus nitens and E. denticulata. Nz J Forestry Sci 41:217-230

Hamilton MG, Blackburn DP, McGavin RL, Baillères H, Vega M, Potts BM (2014) Factors affecting log traits and green rotary-peeled veneer recovery from temperate eucalypt plantations. Ann Forest Sci 72:357-365. https://doi.org/10.1007/s13595-014-0430-0

Harwood C, Raymond C, Ilic J, Williams E, Savage L (2005) Patterns of variation in wood stiffness of plantation-grown Eucalyptus globulus and E. nitens. Technical report no. 156. Cooperative Research Centre for Sustainable Production Forestry, Hobart

Hein PRG, Brancheriau L (2011) Radial variation of microfibril angle and wood density and their relationships in 14-year-old Eucalyptus urophylla S.T. Blake wood. Bioresources 6:3352-3362

Jordan L, Daniels R, Clark A, He R (2005) Multilevel nonlinear mixedeffects models for the modeling of earlywood and latewood microfibril angle. For Sci 51:357-371

Kojima M, Yamamoto H, Yoshida M, Ojio Y, Okumura K (2009) Maturation property of fast-growing hardwood plantation species: a view of fiber length. Forest Ecol Manag 257:15-22. https://doi. org/10.1016/j.foreco.2008.08.012

Lachenbruch B, Moore JR, Evans R (2011) Radial variation in wood structure and function in woody plants, and hypotheses for its occurrence. In: Meinzer FC, Lachenbruch B, Dawson TE (eds) Sizeand age-related changes in tree structure and function, vol 4. Tree physiology. Springer, The Netherlands, pp 121-164. https://doi.org/ 10.1007/978-94-007-1242-3 5

Leban JM, Haines DW (1999) The modulus of elasticity of hybrid larch predicted by density, rings per centimeter, and age. Wood Fiber Sci 31:394-402

Lenz P, Cloutier A, MacKay J, Beaulieu J (2010) Genetic control of wood properties in Picea glauca - an analysis of trends with cambial age. Can J For Res 40:703-715. https://doi.org/10.1139/x10-014

Lima JT, Breese MC, Cahalan CM (2004) Variation in microfibril angle in Eucalyptus clones. Holzforschung 58:160-166. https://doi.org/ 10.1515/Hf.2004.024

Logan M (2010) Multiple and curvilinear regression In: Biostatistical design and analysis using R: a practical guide. Wiley-Blackwell, Chichester, pp 208-253

Maeglin RR (1987) Juvenile wood, tension wood, and growth stress effects on processing hardwoods. In: Applying the latest research to hardwood problems - 15th Annual Hardwood Symposium of the Hardwood Research Council, Memphis, US, May 10-12 1987. Forest Products Laboratory, Memphis, pp 100-108

McGavin R, Bailleres H, Hamilton M, Blackburn D, Vega M, Ozarska B (2014a) Variation in rotary veneer recovery from Australian plantation Eucalyptus globulus and Eucalyptus nitens. Bioresources 10: 313-329

McGavin RL, Bailleres H, Lane F, Blackburn D, Vega M, Ozarska B (2014b) Veneer recovery analysis of plantation eucalypt species using spindleless lathe technology. Bioresources 9:613-627

McGavin RL, Bailleres H, Fehrmann J, Ozarska B (2015) Stiffness and density analysis of rotary veneer recovered from six species of Australian plantation hardwoods. Bioresources 10:6395-6416

McLean JP, Moore JR, Gardiner BA, Lee SJ, Mochan SJ, Jarvis MC (2016) Variation of radial wood properties from genetically improved Sitka spruce growing in the UK. Forestry 89:109-116. https://doi.org/10.1093/forestry/cpv035

Medhurst J, Ottenschlaeger M, Wood M, Harwood C, Beadle C, Valencia JC (2011) Stem eccentricity, crown dry mass distribution, and longitudinal growth strain of plantation-grown Eucalyptus nitens after thinning. Can J For Res 41:2209-2218. https://doi.org/10.1139/ X11-135
Medhurst J, Downes G, Ottenschlaeger M, Harwood C, Evans R, Beadle C (2012) Intra-specific competition and the radial development of wood density, microfibril angle and modulus of elasticity in plantation-grown Eucalyptus nitens. Trees-Struct Funct 26:17711780. https://doi.org/10.1007/s00468-012-0746-z

Mendoza GA, Vanclay JK (2008) Trends in forestry modelling. CAB Reviews: Perspectives in Agriculture, Veterinary Science, Nutrition and Natural Resources 3:8 pp.-8. doi:https://doi.org/10. 1079/PAVSNNR20083010

Moore JR, Cown DJ (2017) Corewood (juvenile wood) and its impact on wood utilisation. Curr Forestry Rep 3:107-118. https://doi.org/10. 1007/s40725-017-0055-2

Moore JR, Cown DJ, McKinley RB (2014) Modelling microfibril angle variation in New Zealand-grown radiata pine. Nz J Forestry Sci 44: 25. https://doi.org/10.1186/s40490-014-0025-4

Mora CR, Allen HL, Daniels RF, Clark A (2007) Modeling corewoodouterwood transition in loblolly pine using wood specific gravity. Can J For Res 37:999-1011. https://doi.org/10.1139/X06-250

Pinheiro J, Bates D, DebRoy S, Sarkar D, EISPACK authors, Heisterkamp S, R Development Core Team (2018) nlme: linear and nonlinear mixed effects Models. R package version 3.1-137

R Development Core Team (2018) R: a language and environment for statistical computing. R Foundation for Statistical Computing, Vienna, Austria., 3.5.2 for Windows edn. http://www.R-project. org/

Ritz C, Streibig J (2008) Grouped data. In: Ritz C, Streibig J (eds) Nonlinear regression with R. Use R. Springer, New York, pp 109 131. https://doi.org/10.1007/978-0-387-09616-2 8

Robinson AP, Hamann JD (2011) Fitting linear hierarchical models. In: Forest analytics with R. Use R. Springer, New York, pp 219-273. https://doi.org/10.1007/978-1-4419-7762-5_7

Salvo L, Leandro L, Contreras H, Cloutier A, Elustondo DM, Ananias RA (2017) Radial variation of density and anatomical features of Eucalyptus nitens trees. Wood Fiber Sci 49:301-311

Sattler DF, Comeau PG, Achim A (2014) Within-tree patterns of wood stiffness for white spruce (Picea glauca) and trembling aspen (Populus tremuloides). Can J For Res 44:162-171. https://doi.org/ 10.1139/cjfr-2013-0150

Vega M, Hamilton MG, Blackburn DP, McGavin RL, Bailleres H, Potts BM (2016) Influence of site, storage and steaming on Eucalyptus nitens log-end splitting. Ann Forest Sci 73:257-266. https://doi.org/ 10.1007/s13595-015-0496-3

Washusen R, Ades P, Evans R, Ilic J, Vinden P (2001) Relationships between density, shrinkage, extractives content and microfibril angle in tension wood from three provenances of 10-year-old Eucalyptus globulus Labill. Holzforschung 55:176-182. https:// doi.org/10.1515/Hf.2001.029

Williams DR, Potts BM, Smethurst PJ (2004) Phosphorus fertiliser can induce earlier vegetative phase change in Eucalyptus nitens. Australian Journal of Botany 52:281-284. https://doi.org/10.1071/ Bt03135

Wimmer R, Downes GM, Evans R (2002) Temporal variation of microfibril angle in Eucalyptus nitens grown in different irrigation regimes. Tree Physiol 22:449-457

Xiang W, Leitch M, Auty D, Duchateau E, Achim A (2014) Radial trends in black spruce wood density can show an age- and growth-related decline. Ann Forest Sci 71:603-615. https://doi.org/10.1007/ s13595-014-0363-7

Zobel BJ, van Buijtenen JP (1989) Wood variation and wood properties. In: Wood variation. Springer series in wood science. Springer, Berlin, pp 1-32. doi:https://doi.org/10.1007/978-3-642-74069-5_1

Publisher's note Springer Nature remains neutral with regard to jurisdictional claims in published maps and institutional affiliations. 